\title{
LEJEUNEA SUBELOBATA AND LEJEUNEA DRUMMONDII (JUNGERMANNIOPSIDA) IN AUSTRALASIA
}

\author{
MATT A. M. RENNER
}

\begin{abstract}
Lejeunea subelobata Carrington \& Pearson has been regarded as a synonym of L. drummondii Taylor, but the two species differ in patterns of variation in lobule morphology, shapes of the gynoecial bracteole, female bract underleaf and vegetative underleaves; in stem anatomy, and ecology. Lejeunea subelobata is a rheophyte from south-east Australia, Tasmania, and New Zealand that grows primarily as a lithophyte on rock within and around waterways, in association with basicolous substrates particularly basalt, rhyolite and andesite. Lobules in L. subelobata are always explanate, the female bract underleaf is obovate, underleaves are rotund and remote, and the stem medulla has 19-26 cells with small concave trigones. Lejeunea drummondii is, in its current circumscription, an ecologically and morphologically malleable taxon confined to Australia. The relationship between L. drummondii and plants from New Zealand described as L. epiphylla Colenso nom. illeg. requires further investigation.
\end{abstract}

Key words: Australia, New Zealand, liverwort, Flora, Lejeuneaceae, synonymy

Matt A. M. Renner, Royal Botanic Gardens and Domain Trust, Mrs Macquaries Road, Sydney, NSW 2000, Australia; e-mail: matt.renner@rbgsyd.nsw.gov.au

\section{INTRODUCTION}

In 1839 James Drummond received from Sir William Jackson Hooker a letter requesting seeds and plants and an offer to dispose of the collections on Drummond's behalf(Sherwood 2010). Six consignments were sent to W. J. Hooker between 1839 and 1852, during which time Drummond resided in the Perth Region (Sherwood 2010). Hooker senior evidently passed Drummond's early bryophyte collections to Joseph Dalton Hooker and Thomas Taylor, who at the time would have been collaborating on the cryptogams collected by J. D. Hooker on the Antarctic voyage of HMS Erebus and Terror between 1840 and 1843. In 1846 Lejeunea drummondii Taylor was named for Drummond on the basis of plants collected by him at 'Swan River' (Taylor 1846). As it is unclear whether Drummond's locality refers to the settlement, the river, or the region, the precise origin of the type is difficult to elucidate, beyond the fact that it must have come from somewhere within what is today the wider Perth region in Western Australia.

Lejeunea drummondii has since been recorded in all states and territories of Australia.
In its current usage it is the most widespread, abundant, and ecologically malleable species of Lejeunea Libert in Australia, occupying an array of forest microsites, from leaves, twigs, branches, trunks, roots, logs, and rocks on the forest floor to rocks within streams, and may even be found growing submerged under running water. Considerable morphological variation has been ascribed to L. drummondii, in keeping with this broad ecological tolerance.

On one of his last visits to New Zealand in 2003, Professor Rudolf M. Schuster identified in the field a rheophytic plant growing submerged on rocks in the Okahu Stream within Herekino State Forest, Northland, as an undescribed species for which he had a manuscript name (R. M. Schuster, pers. comm.). This entity is distinctive in its consistent production of explanate lobules and rheophytic habit. It has proved widespread in New Zealand, and the same as some plants from similar microhabitats in Tasmania, Victoria and New South Wales represented in Australian herbarium material, including the syntypes of Lejeunea 
subelobata Carrington and Pearson (Carrington \& Pearson 1888).

A survey of Australian and New Zealand specimens indicated morphological differences between L. drummondii and L. subelobata that were correlated with habitat. Furthermore, these two species were included in a molecular phylogeny based on nrITS1 and $\operatorname{trn} L-F$, within which they were separated by the basal-most node within the Lejeunea-generic complex (Renner et al. 2011). Though only single representatives of each species were included, high support values were resolved for intervening nodes, and phylogenetic signal was congruent between markers. This suggests subtle morphological differences are significant with regards their ability to circumscribe phylogenetically distinct lineages. However, in this phylogeny L. subelobata was wrongly called $L$. tasmanica Gottsche (Gottsche 1857) due to misinterpretation of type material by the author. Morphological, molecular, and ecological evidence support the recognition of two morphologically and phylogenetically isolated and ecologically different species. Therefore L. subelobata is here reinstated from synonymy under L. drummondii.

\section{MATERIALS AND METHODS}

The morphological descriptions and comparisons are based on observations of Lejeunea populations observed in New South Wales, Tasmania, Victoria, Western Australia (Australia) and New Zealand, and those held in the herbaria AK, BM, CANB, CHR, FH, G, HO, MEL and NSW (Holmgren et al. 1990), using a stereomicroscope and compound microscope. Material was initially identified with reference to Grolle (1982). Digital images of gametophyte structures were captured with a Leica DFC420 camera on a Leica DM2500 compound microscope. Descriptions are based on two specimens considered representative of observed variation for L. subelobata, and from a single western Australian specimen for L. drummondii. Allometric dimensions were measured using ImageJ (Abramoff et al. 2004) calibrated with a slide micrometer, with ranges based on twenty measurements taken haphazardly from each specimen. For rare structures such as perianths and female bracts, ranges are based on the largest and smallest examples observed, and measured using an eyepiece micrometer. Illustrations of plant parts were produced with the aid of an Olympus CH-2 compound microscope with camera lucida attachment.

\section{TAXONOMIC TREATMENT}

Lejeunea drummondii Taylor

Fig. 1

London Journal of Botany 5: 400. 1846. - Eulejeunea drummondii (Taylor) Rodway, Tasmanian Bryophytes 2 (Hepatics): 89. 1916. - TYPE: AUSTRALIA, 'Swan River, Mr. James Drummond'. HolotyPE: FH! IsOTYPES: G-19616! W (Lindenb. Hep. 6440).

Lejeunea gunniana Mitt. in Hooker, Flora Tasmaniae 3: 235. 1859. - Cheilolejeunea gunniana (Mitt.) Steph. Species Hepaticarum 5: 675. 1914. - TYPE: AUSTRALIA 'Tasmania, Gunn' Syntype: BM! 'Brown's River, Oldfield'. SYNTYPE: BM!

Lejeunea luchmannii Steph., Hedwigia 28: 261. 1889. - Strepsilejeunea luchmannii (Steph.) Steph., Species Hepaticarum 5: 292. 1913. - TYPE: AUSTRALIA 'Gippsland, Moe River, ... leg. Luchmann' HolOTYPE: G! ISOTYPES: BM!

Lejeunea tasmanica Gottsche, Linnaea 28: 558. 1857. - Eulejeunea tasmanica (Gottsche) Rodway, Tasmanian Bryophytes 2 (Hepatics): 89. 1916. - Eulejeunea tasmanica (Gottsche) Steph., Species Hepaticarum 6: 653. 1924. - TYPE: AUSTRALIA Tasmania 'Terra Van Diemen', leg. Stuart. LECTOTYPE (Grolle 1982): G-19624!

= Eulejeunea tumida f. parvilobula Rodway, Tasmanian Bryophyta 2: 89. 1916. - TYPE: AUSTRALIA, Tasmania, Mt Field, Rodway (not located).

DESCRIPTION. Forming near pure mats on sedimentary boulders in and around watercourses. Shoots yellow-green to mid-green when fresh, brown in herbaria, medium-sized for genus, shoots to $40 \mathrm{~mm}$ long and $0.8-1.3 \mathrm{~mm}$ wide, branching frequent, shoot system monomorphic or subdimorphic, with leading shoots larger in stature than branches. Stems with external and internal cortical cell walls unthickened, medullar cell walls unthickened, with seven or eight cortical cells and 14-21 smaller medullar cells in transverse section, dorsal leaf-free strip absent. Lobes rotund-ovate, $310-855 \mu \mathrm{m}$ long and $275-645 \mu \mathrm{m}$ wide, contiguous to imbricate, overlapping and obscuring the stem in dorsal view, erecto-patent when moist, same when dry, margins weakly crenulate due to bulging cells; lobe apex broadly rounded to weakly obtuse, all 


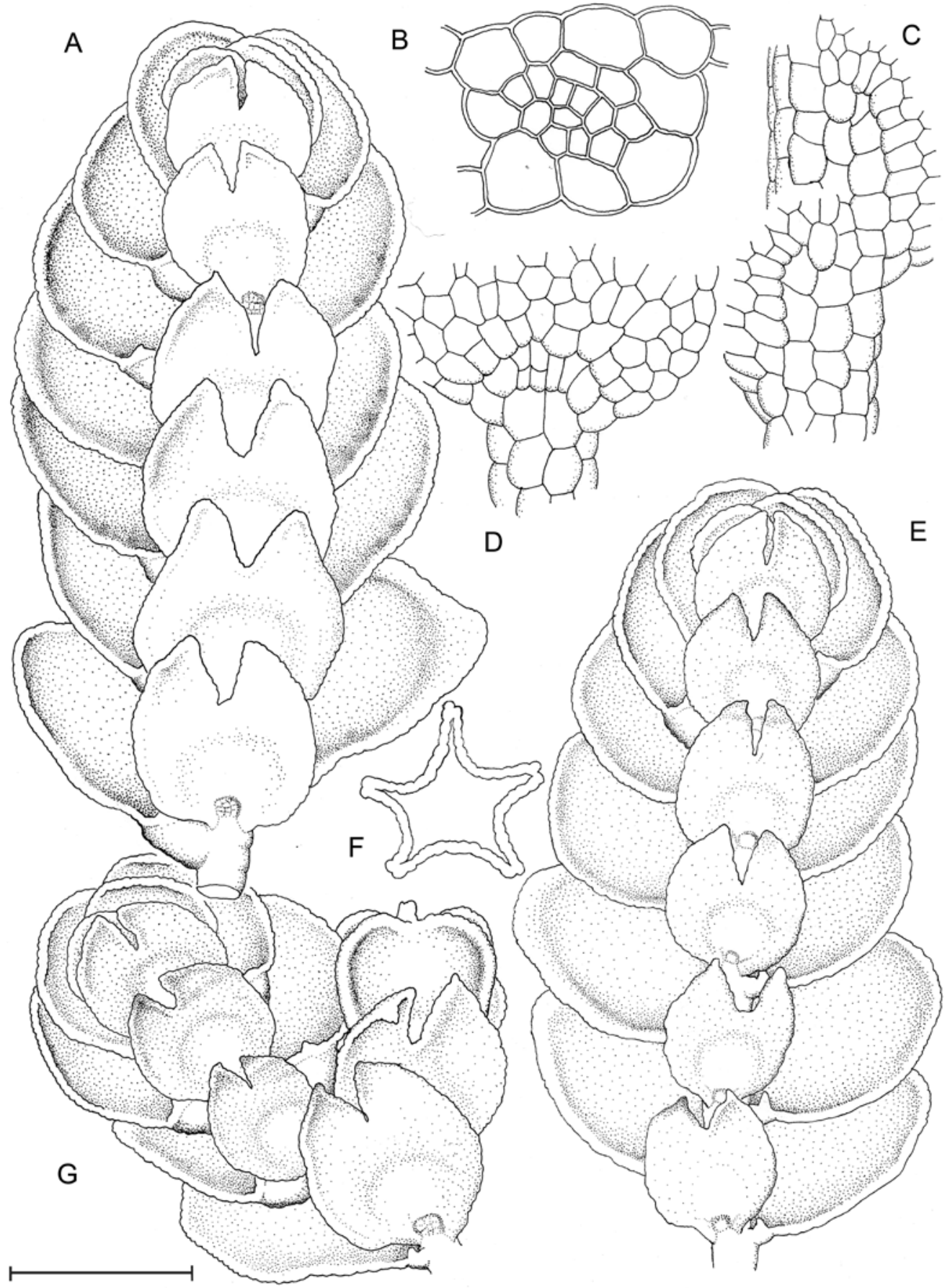

Fig. 1. Lejeunea drummondii Taylor. A - ventral view of robust shoot, B - stem transverse section, the 'ninth cortical cell' belongs to a leaf, $\mathrm{C}$ - stem dorsal view, D - underleaf base, $\mathrm{E}$ - ventral view of weak shoot, $\mathrm{F}$ - perianth transverse section, $\mathrm{G}$ - fertile lateral branch, with gynoecium subtended by sterile subfloral innovation. Scale bar: A, E-G = $500 \mu \mathrm{m} ; \mathrm{B}=100 \mu \mathrm{m}$; C \& D $=200 \mu \mathrm{m}$. All from NSW889060. 
margins curved from keel to apex though slightly at first. Lobules mostly weakly developed, of 20 or more cells, lobules 128-162 $\mu \mathrm{m}$ long and 88$112 \mu \mathrm{m}$ wide, with a prominent first lobule tooth with the lobule papilla attached at its proximal base; explanate lobules occasionally produced, of 8-10 cells and smaller than the reduced lobules, with the papilla affixed to the apex of the first lobule tooth; weakly developed lobules intergrade with normal lobules along shoots; normal lobules 192-240 $\mu \mathrm{m}$ long and 98-125 $\mu \mathrm{m}$ wide, one twentieth the lobe area, with lobule arch straight, 3 cells long; lobe-lobule junction lying postical to the base of the first lobule tooth, first tooth prominent, second tooth unicellular, keel arched with a broadly inflated carinal region. Underleaves contiguous to imbricate, elliptic-ovate, broadest at midpoint, 272-640 $\mu \mathrm{m}$ long and 304-658 $\mu \mathrm{m}$ wide, bifid to 0.5 , sinus narrow or broad, $\mathrm{V}$-shaped, 144-245 $\mu \mathrm{m}$ deep, lobes acute, margins weakly crenulated due to bulging cells; underleaf insertion arched across two or three ventral cortical cells, lateral basal cells of underleaf inflated. Lobe, lobule and underleaf cell surfaces smooth. Lobe cell walls with small triangular trigones and weak medial thickenings. Oil-bodies small, homogeneous, spherical to fusiform, more than thirty per cell arranged in a submarginal ring. Asexual reproduction absent. Autoicous, or mixed autoicous and paroicous. Antheridia either on short, determinate, achlorophyllous lateral branches or on subfloral innovations adjacent to gynoecia, bearing 2-5 pairs of bracts, underleaves at branch base only or at branch base and at basal bract pair, bracts isolobous, epistatic, decreasing in stature along branch, housing 1-2 antheridia each. Gynoecia typically produced on lateral branches, occasionally mid-shoot, subtended by single Lejeuneoid subfloral innovation that either continues vegetative growth or produces androecium and terminates, rarely subtended by two subfloral innovations; female bracts subsymmetrical, one lobe slightly smaller, lobes 400-435 $\mu \mathrm{m}$ long, 290-315 $\mu \mathrm{m}$ wide, obovate, lobule rectangular, 210-260 $\mu \mathrm{m}$ long, margins reflexed, free portion $8-10$ cell tiers high and 4 or 5 rows wide, bract underleaf fused with lobules on both sides, bract underleaves elliptic ovate, squat, 285-320 $\mu \mathrm{m}$ wide, 365-440 $\mu \mathrm{m}$ long, sinus 120 $150 \mu \mathrm{m}$ deep, narrow, lobes broad, apices acute. Perianths $350-420 \mu \mathrm{m}$ diameter and up to 760 long, pentacarinate, carinae prominent; rostrum short; perianth stipe not developed on perianths containing immature sporophytes, perianths with emergent sporophytes not seen.

DISTRIBUTION AND ECOLOGY. As currently circumscribed, L. drummondii is the most widespread Lejeunea species in Australia, being recorded from Western Australia, Tasmania, Victoria, New South Wales and Queensland. On the basis of herbarium material, it is the most abundant Lejeunea in Tasmania, from where several dozen vouchers attributed to this species have been gathered. Lejeunea drummondii occupies a range of habitat types, from tall forest, including cool- and warm-temperate rainforest and subtropical and tropical rainforest, to woodlands, low-forest and heath. In all habitat types it is typically a trunk or branch epiphyte although it may grow as an epiphyll on ferns or as a lithophyte, as at Tulbrinup in Western Australia.

REPRESENTATIVE SPECIMEN EXAMINED: AUSTRALIA. Western Australia: Toolbrinup, on the climbing track from SE, 10 Oct. 2004, M.A.M. Renner 2286 \& E. O'Brien (NSW889060).

RECOGNITION. Lejeunea drummondii is currently circumscribed to include medium to large, mid-green plants with large ovate to rotund underleaves, and penta-carinate perianths. Lejeunea drummondii has smooth leaf-lobe cell surfaces, unlike L. cuspidistipula (Steph.) Steph. ex Watts, L. flava (Sw.) Nees, and L. gracilipes (Taylor) Spruce, (with which it is sometimes confused) which have cells bearing punctate or finely granular ornamentation.

Lejeunea drummondii and L. subelobata have been regarded as morphologically different forms of a single species. The most obvious differences between $L$. drummondii and L. subelobata are in underleaf and lobule morphology. The underleaves of L. drummondii are elliptic-ovate, and contiguous on small-stature shoots through to imbricate on robust shoots. The spacing and width of the underleaves means the lobules of $L$. drummondii are 
almost always obscured in ventral view (Fig. 1). In L. subelobata the underleaves are more or less rotund, and are usually remote (Fig. 2). The spacing and width of the underleaves means the lobules of L. subelobata are visible in ventral view. In terms of variation in lobule morphology, both L. drummondii and L. subelobata produce explanate lobules however, populations of $L$. subelobata rarely if ever produce normal lobules, while $L$. drummondii transitions between explanate and normal lobules as a regular function of shoot stature, such that a spectrum of lobules from explanate to normal can be found on single shoots and robust shoots always bear some normal lobules (Figs 1-3). Perhaps most significantly, Lejeunea drummondii differs from L. subelobata in the shape of its female bracteole and gynoecial bracts. In L. drummondii the female bracteole is broadly elliptic and overlaps the female bracts and bract underleaf, the bract underleaf is also broadly elliptic. In L. subelobata the female bracteole is transversely broadly ovate, and hardly overlaps the female bracts and bract underleaf, which is rectangular-ovate. The stem anatomy of L. drummondii and L. subelobata also exhibits significant differences. In L. drummondii there are seven or rarely eight cortical cell rows, and 14-21 medulla cell rows, whose walls are unthickened. In L. subelobata there are seven to ten cortical cell rows, and 19-26 medulla cell rows whose walls bear small concave trigones at their junctions.

REMARKS. Lejeunea drummondii seems to be the only southern-temperate Australasian Lejeunea species to exhibit paroicy, with some of the androecia produced on the single determinate subfloral innovation subtending the gynoecium (Fig. 2). The regular production of gynoecia on short lateral branches is also distinctive, but not unique. Although L. drummondii can also produce androecia and gynoecia on separate branches, all other regional species familiar to me are exclusively autoicous, with gynoecia and androecia always on separate branches, the androecia being scattered throughout the shoot system. Robust shoots in the type of $L$. drummondii exhibit a mix of paroicous and autoicous androecia and gynoecia. However, the other specimen examined was autoicous only, and androecia were not produced as densely as in the type specimen. Otherwise, the morphology of both specimens was similar and the differences from $L$. subelobata consistent.

The relationship between $L$. drummondii in Australia, and plants from New Zealand described as L. epiphylla Colenso nom. illeg. non Mitt. 1884 (Colenso 1889) requires further investigation, as does the relationship between the type and other mainland Australian plants, and the myriad of Tasmanian forms attributed to this species.

\section{Lejeunea subelobata Carrington \& Pearson}

Figs 2-4

Proceedings of the Linnean Society of New South Wales series 2, 2: 1039. 1888.

$\equiv$ Lejeunea elobata Pearson in Watts, Proceedings of the Linnean Society of New South Wales 27: 493. 1903 '1902' orthographic variant of L. subelobata.

$\equiv$ Eulejeunea subelobata (Carrington \& Pearson) Steph., Hedwigia 28: 170. 1889. - TYPE: New South Wales: near Sydney, Balls Head Bay, June 1888, leg. Whitelegge no. 47. LECTOTYPE (designated by Grolle 1982): BM (2 packets)!; ISOLECTOTYPES: ex herb hort. Kew BM (1 packet)!, G-19832!, JE, MANCH; PARALECTOTYPE: AUSTRALIA. Georges River, Botany Bay, on wet rocks, Jan 1885, T. Whitelegge, No. 42, BM!

DESCRIPTION. Forming pure or near pure radiating mats on igneous (andesitic, rhyolitic, and doleritic) boulders in stream beds, occasionally submerged but typically growing at and immediately above the normal winter base-flow level; also mixed with other bryophytes on rotting logs and soil banks adjacent to or within the water course. Shoots mid-green to black-green when fresh, brown in herbaria, medium sized for genus, shoots to $40 \mathrm{~mm}$ long and $0.8-1.2 \mathrm{~mm}$ wide, branching infrequent, shoot system monomorphic. Stems with external and internal cortical cell walls evenly thickened, medullar cell walls unthickened except for weak concave trigones of primary wall around cell wall junctions, usually seven but up to nine cortical cell rows and 19-26 smaller medullar cell rows; dorsal leaf-free strip absent. Lobes rotund-ovate, 317$719 \mu \mathrm{m}$ long and 275-670 $\mu \mathrm{m}$ wide, contiguous 


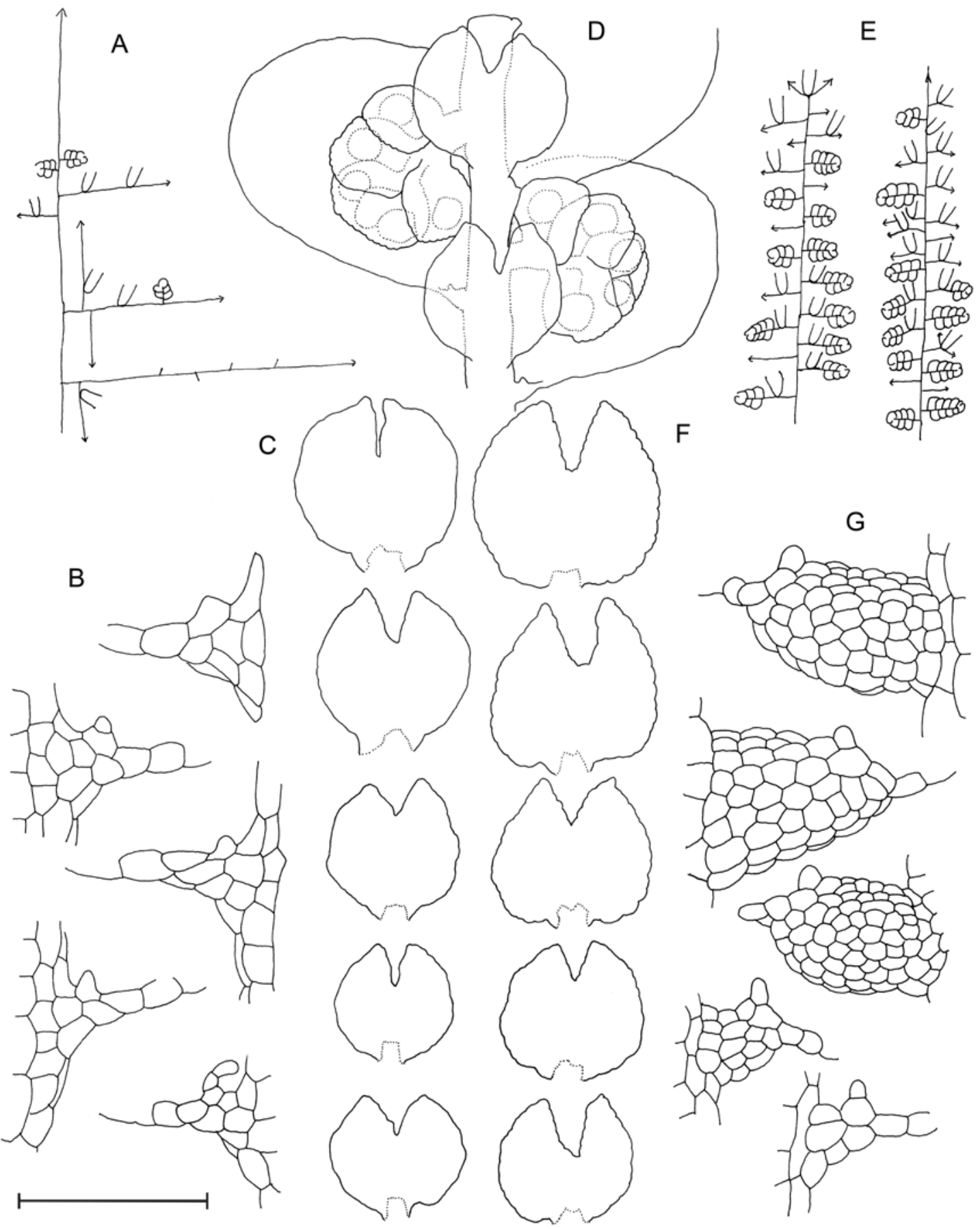

Fig. 2. Lejeunea subelobata Carrington \& Pearson. A - cladogram, B - lobules, C - underleaves, D - androecia. Lejeunea drummondii Taylor. E - cladogram, F - underleaves, $\mathrm{G}$ - lobules. Scale bar: A \& E = $10 \mathrm{~mm}$; B \& G = $100 \mu \mathrm{m}$; C, D \& F = $500 \mu \mathrm{m}$. A-D from NSW872054; E-G from NSW889060. 


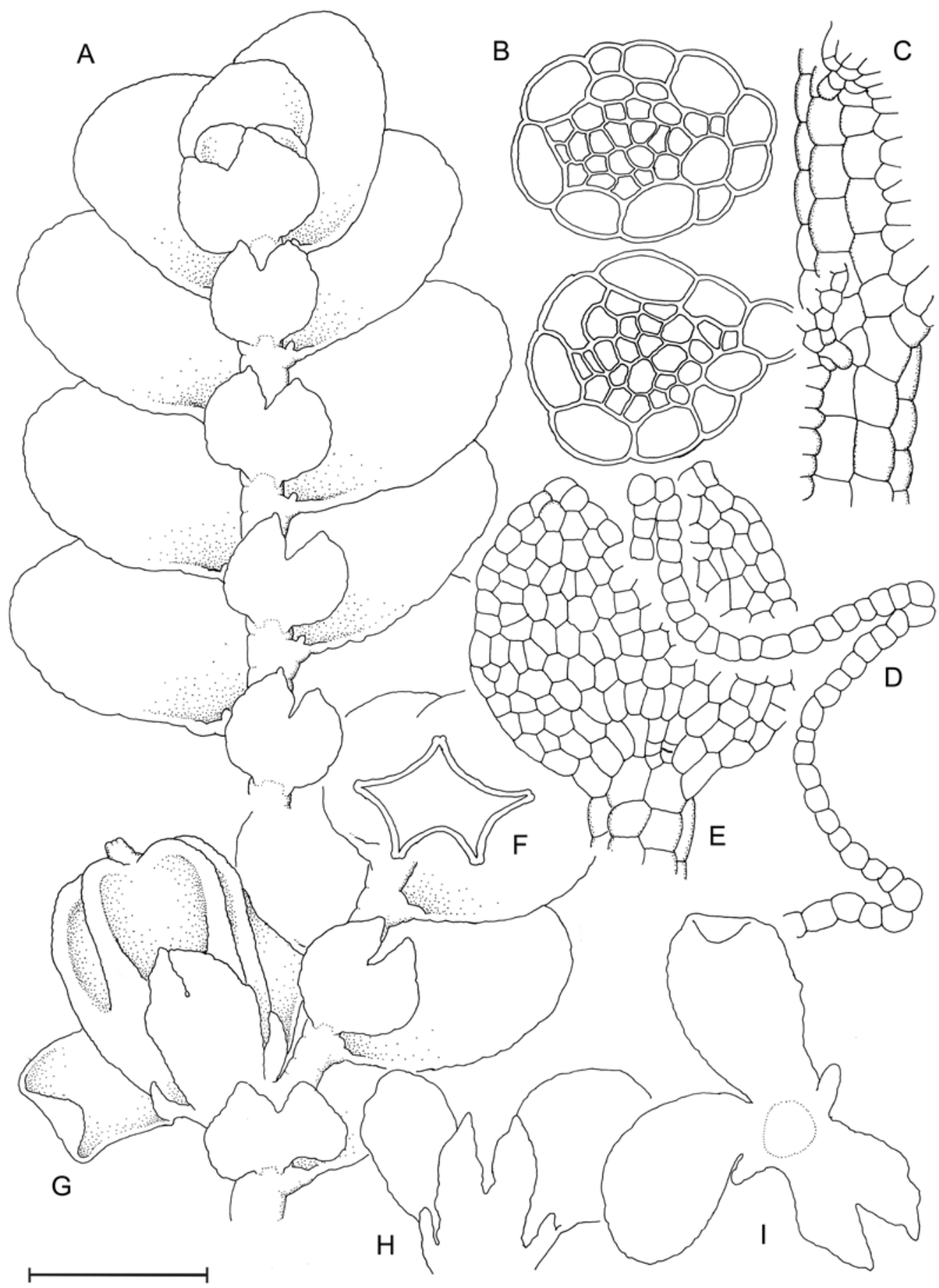

Fig. 3. Lejeunea subelobata Carrington \& Pearson. A - ventral view of typical shoot, B - stem transverse sections, C - stem dorsal view, D - perianth transverse section, E - underleaf. F - perianth transverse section, $\mathrm{G}$ - fertile lateral branch, $\mathrm{H}$ - female bract gyre, in situ, I - female bract gyre, flattened. Scale bar: A \& F-I = $500 \mu \mathrm{m}$; B $=100 \mu \mathrm{m}$; C-E $=200 \mu \mathrm{m}$. All from NSW872054. 
to imbricate, overlapping and obscuring the stem in dorsal view, weakly erecto-patent when moist, same when dry; lobe apex broadly rounded, all margins curved, from keel to apex though slightly at first, margins minutely crenulated due to bulging cells. Lobules mostly or exclusively explanate, 10-24 cells, 43-99 $\mu \mathrm{m}$ long and 56-91 $\mu \mathrm{m}$ wide, with a prominent first lobule tooth to which the lobule papilla is attached at its apex; plants growing on logs produce normal lobules more frequently than those on rock; normal lobules one twentieth the lobe area, with lobule arch straight, 3 cells long; lobe-lobule junction lying postical to the base of the first lobule tooth, first tooth prominent, second tooth unicellular, keel shallowly arched with a broadly but weakly inflated carinal region; normal and explanate lobules may co-occur and inter-grade along a single shoot. Underleaves rotund, broadest at midpoint, $160-357 \mu \mathrm{m}$ long and $148-356 \mu \mathrm{m}$ wide, bifid to 0.4 , sinus narrow or V-shaped, 54-147 $\mu \mathrm{m}$ deep, lobes obtuse to acute; underleaf insertion transverse across two or three ventral cortical cells, lateral basal cells of underleaf inflated. Lobe, lobule and underleaf cell surfaces smooth. Lobe cell walls with small triangular trigones and weak medial thickenings. Oil-bodies small, homogeneous, spherical to fusiform, more than thirty per cell arranged in a submarginal ring. Asexual reproduction absent. Autoicous. Antheridia on short, determinate, achlorophyllous lateral branches bearing 1-3 pairs of bracts, underleaves either absent or at branch base only, or at branch base and at basal bract pair only; bracts isolobous, epistatic, decreasing in stature along branch, housing 1-2 antheridia each. Gynoecia typically produced mid-shoot, occasionally shortly after branching points, subtended by single Lejeuneoid subfloral innovation that continues vegetative growth; female bracteole squat, broadly transversely ovate, female bracts subsymmetrical, one lobe slightly smaller, lobes 560-595 $\mu \mathrm{m}$ long, 270-340 $\mu \mathrm{m}$ wide, obovate, lobule reduced to spur at lobe base, bract underleaf elliptic-oblong, 235$280 \mu \mathrm{m}$ wide, $400-445 \mu \mathrm{m}$ long, sinus to $150 \mu \mathrm{m}$ deep, wide, lobes obtuse, fused with lobules on both sides. Perianths 350-420 $\mu \mathrm{m}$ diameter and up to $460-490 \mu \mathrm{m}$ long, up to $900 \mu \mathrm{m}$ with stipe, pentacarinate, carinae prominent; rostrum short; perianth stipe of enlarged colourless cells at perianth base present in mature perianths with emergent sporophytes.

DisTRIBUTION AND ECOLOGY. Lejeunea $s u b$ elobata is currently known from Australia, and New Zealand. In Australia, L. subelobata occurs east of the Great Dividing Range in Victoria and in Tasmania, in association with cool temperate rainforest growing over igneous bedrock. In New Zealand, L. subelobata occurs in lowland habitats throughout the northern and eastern North Island, and on the eastern side of the South Island, particularly Banks Peninsula, again in areas associated with igneous rocks. Throughout its range, L. subelobata grows on volcanic boulders and bedrock within and alongside watercourses. The basicolous habit of L. subelobata is well illustrated in the middle reaches of catchments draining the northeastern flanks of the Waitakere Ranges, Auckland New Zealand. In the middle reaches the bedrock changes from the volcanically derived Manukau breccia to the sedimentary Waitemata sandstone and mudstone (Brothers 1953). Where boulders derived from both bedrocks are present within streams, L. subelobata grows only on the andesite boulders derived from within the Manukau breccia, and as these are progressively replaced by Waitemata sandstone and mudstone so the abundance of $L$. subelobata declines. In sections of stream with boulders derived exclusively from the Waitemata formation, L. subelobata is absent. Lejeunea subelobata may also grow as an epiphyll on fern leaves (such as Hymenophyllum demissum (G. Forst.) Sw. overhanging waterways, particularly where these are in contact with established patches, or on decaying wood within and adjacent waterways, and occasionally as an epiphyte on trees growing alongside waterways. Lejeunea subelobata is associated with a range of lithophytic and rheophytic species, including the bryophytes Fallaciella gracilis (Hook.f. \& Wils.) Crum, F. robusta Fife, Lopholejeunea sp., Radula strangulata Hook.f. \& Taylor, Metzgeria spp. Camptochaete arbuscula (Sm.) Reichdt., Cratoneuropsis relaxa (Hook.f. \& Wils.) Broth., Pyrrhobryum para- 


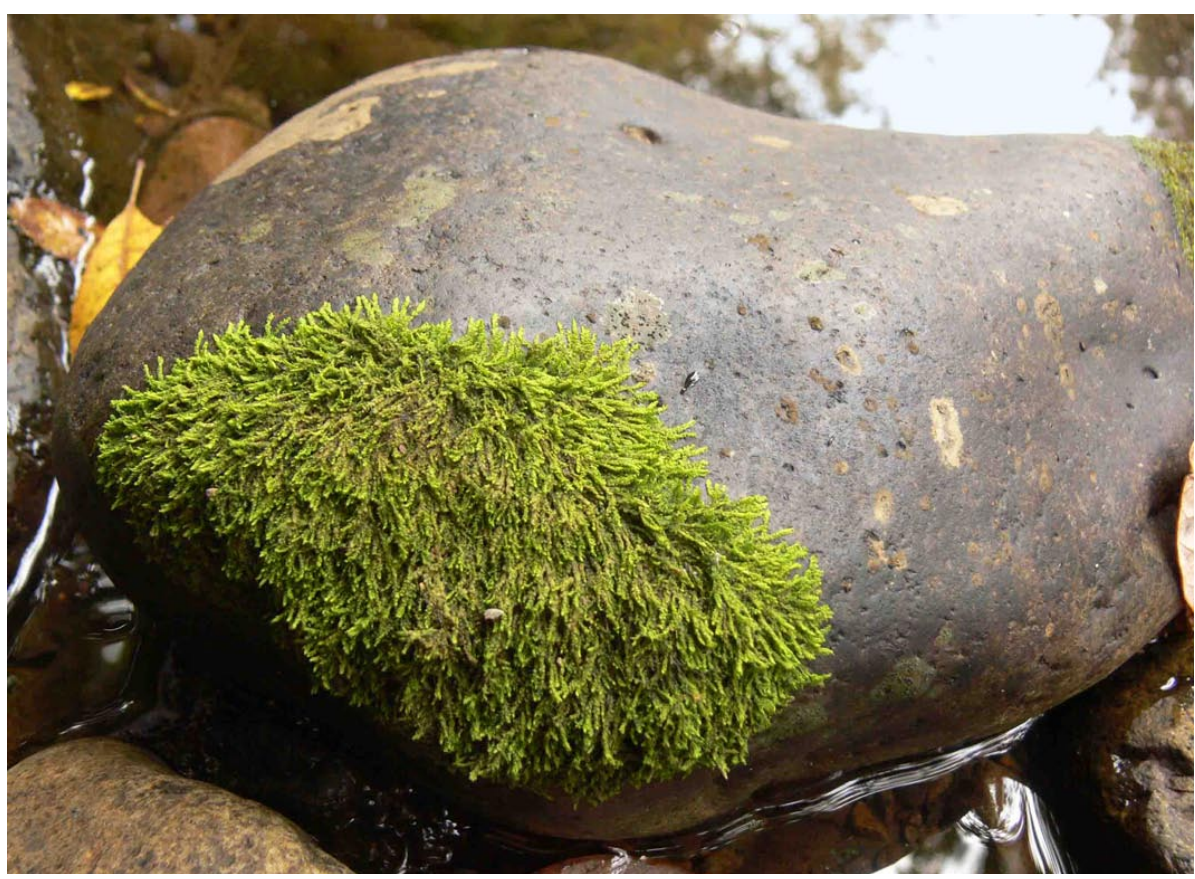

Fig. 4. Lejeunea subelobata Carrington \& Pearson in habitat on basalt boulder in the bed of the Waipoua River, Western Northland Ecological district, North Island, New Zealand. Not vouchered.

mattense (C.Müll.) Manuel, Thuidium furfurosum (Hook.f. \& Wild.) Reichdt., Hypopterygium commutatum C.Müll., Plagiochila gigantea (Hook.) Dumort., Fissidens asplenioides Hedw., and the fern Hymenophyllum demissum.

REPRESENTATIVE SPECIMENS EXAMINED: NEW ZEALAND. North Island, Western Northland Ecological Region, Maungataniwha Ecological District, Herekino State Forest, Okahu Stream, $35^{\circ} 10^{\prime} \mathrm{S}, 173^{\circ} 16^{\prime} \mathrm{E}, 80 \mathrm{~m}, 23$ April 2003, J.E. Braggins \& M.A.M. Renner 404, on rocks within stream (AK282699); Maungamuka Gorge, Picnic area, $35^{\circ} 12^{\prime} 0^{\prime \prime} \mathrm{S}, 173^{\circ} 29^{\prime} 0^{\prime \prime} \mathrm{E}, 70 \mathrm{~m}, 16$ March 2006, R.M. Schuster \& J.E. Braggins 06/030, on rocks at margin of bed of Tepapa Stream (AK296825); ibid, R.M. Schuster \& J.E. Braggins 06/033C, epiphyll on Hymenophyllum demissim on margin of Tepapa Stream (AK296839); Eastern Northland Ecological Region and District, Russell State Forest, Waihaha Stream, $45 \mathrm{~m}, 35^{\circ} 21.323^{\prime} \mathrm{S}$, $174^{\circ} 12.129^{\prime} \mathrm{E}, 14$ Jan. 2009, M.A.M. Renner 4149 \& D.S. Glenny, on boulder in streambed (AK314567); Waitakere Ranges, Destruction Gully, Waitakere Stream, $37^{\circ} 1^{\prime} 48^{\prime \prime} \mathrm{S}, 174^{\circ} 31^{\prime} 31^{\prime \prime} \mathrm{E}, 114$ m, 24 Nov. 2004, M.A.M. Renner 1204, (NSW872054, AK, F); New Zealand, Knight, G-19644; Auckland Ecological Region, Waita- kere Ecological District, Waitakere Ranges, Glen Esk Stream, Kitakita Falls, $36^{\circ} 58^{\prime} \mathrm{S}, 174^{\circ} 29^{\prime} \mathrm{E}, 140 \mathrm{~m}, 25 \mathrm{Apr}$. 1992, J.E. Beever 73.94c (AK256802). AUSTRALIA. Victoria: Volcanic Plain, The Pinnacles west of Byaduk, $37^{\circ} 57^{\prime} \mathrm{S}, 141^{\circ} 57^{\prime} \mathrm{E}, 1950$, A.C. Beauglehole 73283 (MEL1045374); Tasmania: Julius River, near the picnic spot on Sumac Rd, $41^{\circ} 09^{\prime} \mathrm{S}, 145^{\circ} 02^{\prime} \mathrm{E}, 120 \mathrm{~m}$, $30 \mathrm{Jan}$. 1992, J. Jarman s.n. (HO310136); East Coast, Prosser River, 42 ${ }^{\circ} 33^{\prime} \mathrm{S}, 147^{\circ} 50^{\prime} \mathrm{E}, 20 \mathrm{~m}, 5$ May 1990, A. Moscal 19513 (HO302339); Cradle Mountain, 41 441'S, 14557'E, Jan. 1911, L. Rodway s.n. (HO38440).

RECOGNITION. The mid- to dark-green patches on rock or dead wood within watercourses at or immediately above winter normal flow levels are good indicators that L. subelobata is at hand (Fig. 4). However, in Australia L. drummondii may occur in the same habitat, so micromorphological characters must be assessed (Table 1). In Tasmania and Victoria L. subelobata has been understandably confused with $L$. drummondii, and L. subelobata is illustrated as L. drummondii in both Meagher and Fuhrer (2003: 251) and Jarman and Fuhrer (1995: 98). 
Table 1. Characters differentiating L. drummondii Taylor and L. subelobata Carrington \& Pearson.

\begin{tabular}{lll}
\hline Character & Lejeunea drummondii & Lejeunea subelobata \\
\hline Sexuality & Paroicous and autoicous & Exclusively autoicous \\
Androecia & $2-5$ bract pairs & $1-3$ bract pairs \\
Gynoecia production & Lateral branches, regular. & Leading axes or branches, scattered. \\
Female bract underleaf & Elliptic & Elliptic-oblong \\
Female bracteole & Elliptic & Broadly transversely ovate \\
Lobe imbrication & Imbricate & Contiguous to imbricate \\
Normal lobules & Usually frequent & Very rare \\
Stem cell walls & Unthickened & Concave trigones \\
Number of medulla cell rows & $14-21$ & $19-26$ \\
Underleaves & Ovate, imbricate on robust shoots. & Rotund, remote at most contiguous on robust shoots. \\
\hline
\end{tabular}

Lejeunea subelobata is one of the few southern temperate Australasian species of Lejeunea that produce explanate lobules almost exclusively. Individuals rarely if ever produce normal fully developed lobules. Only two other regional entities share this characteristic. Some morphs of L. drummondii have a similar tendency toward exclusive production of explanate lobules, particularly corticolous plants from Tasmania, as represented in the type of L. tasmanica. Lejeunea subelobata was wrongly called L. tasmanica in the phylogeny of Renner et al. (2011) due to a misinterpretation of L. tasmanica's type. The recognition of L. drummondii, of which L. tasmanica is a synonym, is discussed above. Another species that produces primarily explanate lobules is a poorly known, smaller, lithophytic plant that grows on limestone within lowland forest settings in the central and western North Island of New Zealand. The identity and relationships of these calcicolous plants requires further investigation.

\section{DISCUSSION}

The reinstatement of Lejeunea subelobata brings to 24 the number of Lejeunea species accepted for Australia (based on McCarthy 2003), and to 16 the number of Lejeunea species reported for New Zealand (Glenny 1998; Renner et al. 2010; Renner \& de Lange 2011).

The wide phylogenetic disparity between phenetically similar plants previously attributed to L. drummondii parallels the situation resolved recently within the L. tumida Mitt. aggregate (Renner et al. 2011). With L. subelobata included, L. drummondii exhibits polyphyly as extreme as that identified within L. tumida. Both L. drummondii and L. tumida emphasize the significance and relevance of subtle homologous morphological character differences to species circumscription. Unfortunately, homologies have sometimes been overlooked or interpreted as infra-specific variation in investigations of the Lejeuneaceae. Justification for differentiating infra- from inter-specific variation within this family is given by ReinerDrehwald (2010). Cryptic morphological diversity within the Lejeuneaceae has been resolved by molecular data in other genera (Heinrichs et al. 2009), and Lejeunea drummondii and L. subelobata might be considered another example of morphologically cryptic species diversity, given the previous synonymy and phenetic similarity between taxa. However, as Johnson \& Cairns-Heath (2010) pointed out, cryptic species complexes evaporate upon discovery of diagnostic characters for distinguishing each species. In the case of L. drummondii and L. subelobata, diagnostic characters exist in the shape of the female bracteole and stem anatomy. Indeed, an assessment of the significance of subtle, yet consistent, differences may best be made in concert with molecular data. For L. subelobata, molecular data, albeit a single accession, help substantiate subtle morphological and ecological differences from $L$. drummondii. Studies of Lejeuneaceae revisiting homology statements in lieu of molecular phylogenies have found 
diversity in homologous morphological character states mirroring underlying phylogenetic diversity, suggesting morphology can provide a sound basis for both proposing and testing hypotheses of relationship (Renner et al. 2010).

ACKNOWLEDGEMENTS. This study was partly supported by an Australian Biological Resources Study (ABRS) Postdoctoral Fellowship awarded to M. A. M. Renner, in collaboration with N. Devos, E. A. Brown and the Royal Botanic Gardens \& Domain Trust (grant RFL210-36B), and partly supported by an Australian Postgraduate Award, and funding from the Hansjörg Eichler Research fund of the Australasian Systematic Botany Society. The author acknowledges the Early Land Plants Today (ELPT) website and unpublished database for assistance with nomenclatural references and citations; Gabe Miller, Jonathan Renner and Trammy Hoang, Matt von Konrat and Genea Pitts, and Eleanor O'Brien for accommodation in Boston, London, Chicago and Perth respectively; Genevive Lewis-Gentry (FH), Len Ellis (BM), Michelle Price $(G)$ and Matt von Konrat (F) for permission to visit and assistance within their herbaria; Barbara Thiers (NY) for feedback on the draft manuscript; David Glenny, Matt J. von Konrat and two anonymous reviewers for improvements suggested to the manuscript.

\section{REFERENCES}

Abramoff M. D., Magelhaes P. J. \& RAM S. J. 2004. Image Processing with ImageJ. Biophotonics International 11: 36-42.

BROTHERS R. N. 1953. The relationship of Waitemata formation and the Manukau breccia, Auckland, New Zealand. Trans. \& Proc. Roy. Soc. New Zealand 81: 521-538.

CArrington B. \& Pearson W. H. 1888. List of Hepaticae collected by Mr Thomas Whitelegge in New South Wales, 1884-1885. Proc. Linn. Soc. New South Wales 2(2): 1035-1060.

COLENSO W. C. 1889. A description of some newly-discovered Cryptogamic Plants; being a further contribution towards the making known the botany of New Zealand. Trans. \& Proc. New Zealand Inst. 21: 43-80.

GLENNY D. 1998. A revised checklist of New Zealand Liverworts and Hornworts. Tuhinga 10: 119-149.

GotTsche C. M. ['1856'] 1857. Plantae Muellerianae: Hepaticae Australiae a Dre. Ferd. Muller lectae. Linnaea 28: 547-561.
Grolle R. 1982. Übersicht der Lejeuneaceae in Tasmanien. Wiss. Z. Friedrich-Schiller-Univ. Jena, Math.-Naturwiss. Reihe 31: 207-227.

Heinrichs J., Klugmann F., Hentschel J. \& SchneIDER H. 2009. DNA taxonomy, cryptic speciation and diversification of the Neotropical-African liverwort, Marchesinia brachiata (Lejeuneaceae, Porellales). Molec. Phylogenet. Evol. 53: 113-121.

Holmgren P. K., Holmgren N. H. \& Barnett L. C. 1990. Index Herbariorum. Part I: The herbaria of the world, ed. 8. Regnum Veg. 120: 1-693.

JARMAN S. J. \& FUHRER B. A. 1995. Mosses and liverworts of rainforest in Tasmania and south-eastern Australia. CSIRO Publications, Melbourne.

JoHnSON L. A. \& CAIRNS-HEATH H. 2010. Decrypting cryptic species: morphological and molecular evidence for recognizing Navarretia linearifolia as distinct from $N$. sinistra (Polemoniaceae). Syst. Bot. 35: 618-628.

MCCARThY P. 2003. Catalogue of Australian Liverworts and Hornworts. Flora of Australia Supplementary series 21. Australian Biological Resources Study, Canberra.

MEAGHer D. \& FuHRER B. A. 2003. A field guide to the mosses $\&$ allied plants of southern Australia. Flora of Australia supplementary series 20. Australian Biological Resources Study, Canberra.

REINER-DREHWALD M. E. 2010. A taxonomic revision of Lejeunea deplanata (Lejeuneaceae, Marchantiophyta) from tropical America. Nova Hedwigia 91: 519-532.

RenNer M. A. M. \& DE LANGE P. J. 2011. Additions to the Lejeuneaceae flora of New Zealand: new species from the Kermadec Islands and range extensions of New Zealand species into the South Pacific. New Zealand J. Bot. 49: $421-433$.

Renner M. A. M., Brown E. A. \& Wardle G. M. 2010. The Lejeunea tumida species group (Lejeuneaceae: Jungermanniopsida) in New Zealand. Austral. Syst. Bot. 23: 443-462.

Renner M. A. M., Brown E. A. \& Wardle G. M. 2011. The Lejeunea tumida species group is positively polyphyletic (Lejeuneaceae: Jungermanniopsida). Austral. Syst. Bot. 24: $10-18$.

SHERwOOD B. R. 2010. James Drummond and the Swan River colony. The Linnean 26(3): 19- 26.

TAYLOR T. 1846. New Hepaticae. London J. Bot. 5: 258-284 \& 365-417. 